\section{Etos intrygi narracyjnej}

Walerij Igoriewicz Tiupa

TEKSTY DRUGIE 2021, NR 2, S. 214-226

DOI: $10.18318 /$ td.2021.2.13 | ORCID: 0000-0002-1688-2787
Źródło: W.I. Tiupa,

Etos narratiwnoj

intrigi, „Wiestnik

RGGU”, Sieria „Istorija.

Fiłołogija. Kulturołogija.

Wostokowiedienije"

2015 № 2, s. 9-19. Tekst

oryginału został

udostępniony na licencji

Creative Commons

Attribution 4.0 License

(CC-BY), https://history.

rsuh.ru/jour/article/view/13.
W sferze estetycznej twórczości słownej (biorąc pod uwagę wielką literaturę, a nie rzemiosło literackie) odbiór artystyczny dzieła stanowi przedmiot zainteresowania zarówno po pierwszej, jak i kolejnej lekturze. Kiedy ponownie czytamy tekst, przeżywamy radość poznawania, a nie powtarzania: przeobrażający się podmiot percepcji - wszak nieprzerwanie zmieniamy się nie tylko zewnętrznie, ale i wewnętrznie - dokonuje bezprecedensowej i niepowtarzalnej aktualizacji tekstu, tzn. realizuje nowe zdarzenie komunikacyjne. Thomas Mann twierdził wręcz, że w pełni odpowiedni odbiór artystyczny jest możliwy dopiero po powtórnym przeczytaniu arcydzieła.

Zakończenie opowiedzianej przez pisarza historii po pierwszej lekturze jest nam jednak znane, nie zmienia się. Przy całej różnorodności możliwych wrażeń po kolejnych czytaniach nieprzemijalność intrygi arcydzieła literackiego pozostaje nie do końca wyjaśniona. Mój dalszy wywód będzie poświęcony właśnie temu problemowi.

\section{Walerij I.Tiupa}

(ur. 1945 r.) - prof.

Rosyjskiego

Państwowego

Uniwersytetu

Humanistycznego

w Moskwie

(RGGU), rosyjski

literaturoznawca,

autor publikacji

naukowych z zakresu

teorii literatury,

teorii komunikacji

i analizy dyskursu,

komparatystyki

i narratologii.

Opublikował m.in.:

Chudożestwiennost'

litieraturnowo

proizwiedienija

(1987), Analitika

chudożestwiennowo

(2001), Litieratura

imientalnost'(2009). 
Podstawowa antynomia zachodniej narratologii polega na rozgraniczaniu historii i dyskursu. Moim zdaniem jest to przeciwstawienie dalekie od słuszności.

Opowiadana his to ria i opowiadający ją dy skurs stale sobie towarzyszą. Poza opowiadaniem nie ma żadnych historii, poza opowiadaniem zachodzą procesy istnienia (naturalne, przypadkowe, prawdopodobne). Niektóre ogniwa tych procesów stają się zdarzeniami i łączą się w his to rię jedynie w dy s kur s i e opowiadania. Historia pełni referencyjną fu n k cję dyskursu, nie jest jego materiałem, nie jest fa bułą rosyjskiej szkoły formalnej. Jak podkreśla Wolf Schmid, „historia jest wynikiem sensotwórczej selekcji elementów spośród zdarzeń, przekształcającej nieskończoność zdarzeń w ograniczoną, znaczącą formację"1.

Jeśli więc, jak twierdził Gérard Genette, narracja „może istnieć dopóty, dopóki opowiada pewną historię, przy której braku dyskurs nie jest narracyjny², to okazuje się, że nieopowiedziana historia jest także h i s t o r i ą, że zdarzenie jest możliwe także bez aktualizującej jego zdarzeniowość świadomości „świadka i sędziego" (Bachtin).

Dyskurs, zgodnie z Teunem van Dijkiem, jest w istocie szerszy od tekstu opowiadania - to wielowymiarowe „zdarzenie komunikacyjne”, zawierające "mówiącego i słuchających, ich predyspozycje indywidualne i społeczne, inne aspekty sytuacji społecznej"3. Dyskurs narracyjny zakłada nierozerwalną jedność zarówno myślanej przez współrozmówców historii, jak i jej reprezentacji przez narratora, a także jej odbioru przez adresata.

Niemal równocześnie z pojawieniem się klasycznej pracy o Proustowskiej narracji autorstwa Genette'a (Discourse narrative [Dyskurs narracyjny], 1972) Michaił Bachtin uzupełnił swoją wczesną książkę Formy czasu i czasoprzestrzeni w powieści (Formy wriemieni i chronotopa w romanie) o rozdział Końcowe uwagi (Zakluczitielnyje zamieczanija, 1973.), w którym m.in. dokładnie wyłożył zasadniczą swoistość wypowiedzi powieściowej jako wypowiedzi narracyjnej:

przed nami dwa zdarzenia - zdarzenie, o którym opowiedziano w utworze, oraz zdarzenie samego opowiadania, w którym sami bierzemy udział jako słuchacze-czytelnicy; zdarzenia te dzieją się w różnych czasach

1 W. Szmid Narratołogija, Jazyki sławianskoj kultury, Moskwa 2008, s. 154.

2 Ż.Żenett Raboty po poetikie. Figury, t. 2, pieriewod Je. Wasiljewa i dr., Izdatielstwo M. i S. Sabasznikowych, Moskwa 1998, s. 66.

3 T.A. wan Diejk /azyk, poznanije, kommunikacija, Progries, M. Dmitrowskaja, Moskwa 1989, s. 122. 
(różnych także pod względem długości trwania) i w różnych miejscach, zarazem zdarzenia te są nierozerwalnie połączone w jednym złożonym zdarzeniu, które możemy określić jako utwór w jego zdarzeniowej pełni [...]. Przy tym odbieramy tę zdarzeniową pełnię jako coś całkowitego i niepodzielnego, rozumiejąc jednocześnie całą niejednorodność składających się na nią momentów. ${ }^{4}$

U Bachtina daje się zauważyć jeszcze trzecie, receptywne, zdarzenie wrażenia po lekturze opowiadania. Podobnie jak referencyjne (opowiedziane), zdarzenie jest również zależne pod względem funkcjonalnym od komunikacyjnego zdarzenia samego opowiadania (czynności). Przy czym jednocześnie jest to szczególne, niesprowadzające się do pierwszych dwóch mentalne zdarzenie w życiu danego czytelnika-słuchacza.

We współczesnych teoriach narratologicznych jak dotąd nie poświęca się jednak wystarczającej uwagi receptywnemu aspektowi narracji. Przyjąwszy zaproponowane przez Wolfganga Isera (1972 r.) pojęcie i mplicy t n e go c zy tel nika i jego synonimy, narratologia wciąż nie dysponuje operacyjnym podejściem do analizy modelowania adresata opowiadania za pomocą tekstu opowiadania.

Wyjątkowa na tym tle była praca Paula Ricoeura Temps et récit (1985), do tej pory zresztą wyraźnie niedoceniana przez większość narratologów. Ricoeur obrał sobie za cel konstrukcję tekstu narracyjnego w odniesieniu do „świata życia czytelnika, bez którego znaczenie dzieła literackiego jest niekompletne"5. Biorąc pod uwagę to, „czego uczyli Bachtin, Genette, Łotman i Uspienski" (t. 2, s. 242), sięgnął po pojęcie in tryg i, które pojawiło się już wcześniej u Paula Veyne'a ${ }^{6}$. „Rozszerzając i pogłębiając pojęcie intrygi" (t. 2, s. 241), Ricoeur połączył w nim mythos Arystotelesa, emplotment Haydena White'a, po części modus Northropa Frye'a, podkreślając adresowalność (przy wykorzystaniu katharsis Arystotelesa) i objaśniającą funkcję badanego zjawiska. W efekcie wypracował specjalną kategorię teoretyczną

4 M. Bachtin Formy czasu i czasoprzestrzeni w powieści, w: tegoż Problemy literatury i estetyki, przeł. W. Grajewski, Czytelnik, Warszawa 1982, s. 484.

5 P. Ricoeur Czas i opowieść, t. 2: Konfiguracja w opowieści fikcyjnej, przeł. J. Jakubowski, Wydawnictwo UJ, Kraków 2008, s. 250. Dalej cytaty według tego wydania umieszczono w tekście, numer tomu i strony podano w nawiasach.

6 P. Veyne Comment on écrit I'histoire, Seuil, Paris 1971. 
intryg i narracy jnej, uzupełniającą aspekty referencyjny i kreacyjny narracji o aspekt receptywny, tworząc trójpłaszczyznową całość zdarzenia komunikacyjnego.

„[...] sens podstawowego działania konfigurującego intrygę"7 zgodnie z Ricoeurem, „różnorodność epizodów przekształca w jedną i kompletną historię" (t. 2, s. 18), przygotowaną tym samym do receptywnej prefig u racji świadomości czytelnika. Posługując się językiem sjuże to cen try c z n e g o rodzimego literaturoznawstwa, można powiedzieć, że intryga według Ricoeura jest sjużetem skupionym nie na fabule, lecz na czytelniku, tzn. sjużetem rozpatrywanym w aspekcie zainteresowania czytelnika. Jeśli jesteśmy słuchaczami jakiegoś opowiadania (nawet mało zaciekawionymi, obojętnymi), to i tak nie sposób uniknąć wyczekiwania na to, jak się zakończy przedstawiana nam historia. Taki efekt narracyjnego oczekiwania Michaił Bułhakow ironicznie przedstawia w epilogu Mistrza i Małgorzaty: „A swoją

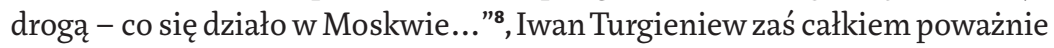
wtóruje mu w końcówce Ojców i dzieci, wymieniając, jak potoczyły się dalsze losy każdej postaci.

Intryga narracji zasadza się na napięciu łańcucha zdarzeniowego, tak by wzbudzić pewne receptywne oczekiwania, z założeniem „zaspokojenia oczekiwań wywołanych przez dynamizm dzieła" (t. 2, s. 40). Intryga narracji, jak trafnie zauważył Osip Mandelsztam, będąc „siłą napędową zainteresowania" , stanowi propozycję alternatywną wobec e n ty me $\mathrm{mu}$ narracyjnego polegającego na przemilczeniu rozwinięcia łańcucha zdarzeniowego w taki sposób, by czytelnik z łatwością się go domyślił¹0. Taką intrygę Ricoeur nazywa "korelatem pojmowania narracyjnego" (t. 2, s. 22), definiując ją jako „jedność teleologiczną" (t. 2, s. 62) opowiadania;

7 P. Ricoeur Czas i opowieść, t. 1: Intryga i historyczna opowieść, przeł. M. Frankiewicz, Wydawnictwo UJ, Kraków 2008, s. 84. Dalej cytaty według tego wydania umieszczono w tekście, numer tomu i strony podano w nawiasach.

8 M. Bułhakow Mistrz i Małgorzata, przeł. I. Lewandowska, W. Dąbrowski, Muza, Warszawa 2004, S. 524 .

9 O. Mandelsztam Słowo i kultura, przeł. R. Przybylski, Czytelnik, Warszawa 1972, s. 151.

Przypomnę, że w retoryce Arystotelesa entymem jest rozumiany jako skrócona argumentacja, której pomijaną część uważa się za oczywistą i którą słuchacze dopowiadają sobie sami. Por. końcówkę Opowieści Biełkina (Powiesti Biełkina) Aleksandra Puszkina: „Czytelnicy zechcą uwolnić mnie od zbędnego obowiązku opisywania finału". A. Puszkin Opowieści Biełkina, przeł. S. Pollak, w: tegoż Opowieści, przeł. S. Pollak, T. Stępniewski, S. Strumph-Wojtkiewicz, Zakład Narodowy im. Ossolińskich, Wrocław 1973, s. 89. 
jako „zasadę selekcji” (t. 2, s. 77) alternatywnych możliwości opowiadania; jako „zasadę konfiguracji” (t. 2, s. 22) epizodów; jako „scalający czynnik” (t. 2, s. 62) segmentów tekstu w określonej kolejności; jako treściowe "trwanie rozciągające się między początkiem a końcem” (t. 2, s. 68).W nią właśnie na powrót wchodzimy, po raz kolejny czytając arcydzieło. „[...] w tym sensie Biblia jest monumentalną intrygą dziejów świata, a każda intryga literacka stanowi rodzaj miniatury wielkiej intrygi łączącej Apokalipsę i Księgę Rodzaju" (t. 2, s. 41-42).

Intryga narracji zatem jako ta, która charakteryzuje receptywny aspekt opowiadania, jest organizowaniem oczekiwania czytelnika. W danym zdarzeniu narracyjnym można wyróżnić dwa aspekty: ro z p a d ciągłego biegu życia na fraktalne epizody i s c a la n i e ich w całościowe opowiadanie, przedstawiające historię. Te różnokierunkowe działania są nieuniknione, ponieważ czas opowiadania i czas opowiadany nie są równe pod względem rozpiętości, a ponadto różnią się jakościowo: czas historii jest wielowymiarowy i kontynuacyjny, podczas gdy mowa dyskursywna - jednowymiarowa i odrębna. Wynika stąd niemożność usunięcia „d r u g i e g o pl a n u budowania intrygi" (t. 1, s. 220). Nie jest to jednak wadą czy słabą stroną wypowiedzi narracyjnych - to ich zasób semantyczny, źródło szczególnych możliwości sensotwórczych. Dotyczy to przede wszystkim narracji literackiej.

Nieunikniona epizodyczna budowa tekstu narracyjnego wynika z konieczności wydzielenia tego, czemu jest przypisywany status zdarzeniowości, z procesualnej ciągłości bytu, tzn. z konieczności wyznaczenia granic czasowo-przestrzennych, centrów aktantnych i semantycznego znaczenia zdarzeniowych komponentów h i s t o r i i. Taka czy inna struktura narracyjna opowiadania, wielokrotnie się powtarzając, historycznie przybiera (gromadzi) swoistą perspektywę semantyczną i obdarza tym znaczeniem narracyjny łańcuch zdarzeniowy, nawet niezależnie od autorskiej woli opowiadającego. Zgodnie z myślą Ricoeura historia bowiem, ,aby stać się logiką opowieści, musi się [...] zwrócić w stronę kulturowo uznanych konfiguracji, w stronę [...] schematyzmu opowieści [...]. Działanie może zostać opowiedziane jedynie dzięki temu schematyzmowi" (t. 2, s. 75).

W sekwencji epizodów zawarty jest klucz zarówno do punktu widzenia narratora, jak i do kształtowanego przez narrację horyzontu wartości adresata opowiadania. Łańcuch elementów rozwijających fabułę w intrygę, równy pod względem rozpiętości tekstowi narracyjnemu, tworzy zgodny treściowo system powiązań: sekwencji narastania albo spadku, periodycznych następstw, powtórzenia, podobieństwa albo kontrastu; niektóre epizody zostały 
wyodrębnione w pozycji początkowej, końcowej, centralnej lub zło tego podziału.

Na granicy epizodów pojawia się fraktalny rozpad opowiadanego świata: czasowy, przestrzenny, aktantowy, albo dwa, trzy takie rozpady jednocześnie. To właśnie przerwy w przedstawianej historii, jakkolwiek wydawałyby się krótkie, wywołują napięcie oczekiwania, ponieważ każda semantyczna pauza (podobnie jak pauza intonacyjna w opowiadaniu ustnym) tworzy ro z w i d le ni e alternatywnych perspektyw kontynuacji.

Czytelnik rozpoznaje perspektywy kontynuacji opowiadania (w większości automatycznie, bez specjalnego zastanawiania się) dzięki, jak twierdził Ricoeur, „naszej zdolności śledzenia historii i osiągniętej zażyłości z tradycją narracyjną" (t. 2, s. 94). Dlatego literacka „intryga musi być typowa”, ponieważ właśnie „uniwersalizacja intrygi uniwersalizuje postaci” (t. 1, s. 67) artystycznego uogólnienia.

Co zaś tyczy się ty powo ści intrygi narracyjnej, to z jednej strony określa się ją jako przynależność łańcucha epizodycznego do tego czy innego typu budowy sjużetu (kulminacyjnego, cyklicznego, liminalnego lub oparty na perypetiach), a z drugiej - przynależność danej narracji do pewnej epoki kulturowej, w szczególności do rudymentarnej dla tej epoki formacji dyskursywnej".

Uczestnictwo w określonej formacji dyskursywnej oznacza, że rozwój intrygi wypowiedzi narracyjnej jest równoważny projektowaniu odbiorców jako solidarnej wspólnoty komunikacyjnej słuchaczy. Strategia narracyjna ${ }^{12}$ opowiadania poprzez wszystkie swoje zasadnicze elementy (narracyjny obraz świata, narracyjną modalność fokalizacji, logos narracyjności) zakłada strategicznie określoną postawę zwrotną wirtualnego adresata. Dyskurs narracyjny, podobnie jak każdy dyskurs kulturowo znaczący również implicite, zawiera „typową koncepcję adresatów” (Bachtin), która od czasów retoryki klasycznej była nazywana e to s e m i charakteryzowała receptywne nastawienie odbiorców.

Dla starożytnych Greków słowo et o s, czyli obyczaj, oznaczało pewną regulacyjną zasadę moralności i wynikającego z niej zachowania. Etos

11 Zob. W.I. Tiupa Diskursiwnyje formacyi: Oczerki po komparatiwnoj ritorikie, Jazyki sławianskich kultur, Moskwa 2010.

12 V. Tjupa Narrative Strategies, w: Handbook of narratology, Walter de Gruyter, Berlin-Boston 2014, vol. 2, s. 564-574; W.I. Tiupa Katiegorija narratiwnych stratiegij, w: Siemiosfiera narratołogii, Nikołajew, Bałaszow 2013, s. 50-58. 
retoryczny był regulacyjną zasadą zachowania receptywnego, którą orator powinien wyzwalać u swoich słuchaczy i na której powinien się opierać w swojej argumentacji. Definiując etos jako „afektywny stan odbiorcy, który powstaje w wyniku oddziaływania na niego jakiejś wiadomości"13 ${ }^{\text {, neoreto- }}$ rycy g r u py $\mu$ słusznie mówią, że „istotę etosu utworu należy upatrywać w integracji wszystkich jego elementów, w interferencjach, konwergencjach, napięciach, jakie przy tym powstają"14. Dla dyskursu narracyjnego takiego rodzaju integratorem tekstu jest intryga.

Zdarzeniowość opowiadania może być realizowana jedynie przez słuchacza (czytelnika), w którego świadomości intryga się urzeczywistnia. Bez słuchacza nie istnieje opowiadanie, a opowiedzieć historii samemu sobie nie jesteśmy w stanie: jest obecna w naszej świadomości jako pełne cząstki doświadczenia, które można rozwinąć w łańcuch epizodów tylko na horyzoncie cudzej świadomości. Dyskurs zakłada nieodwołanie „przewidywane słowo odpowiedzi”, odbierane przez mówiącego „jako sprzeciw albo poparcie”15. Innymi słowy, dowolne zdarzenie komunikacyjne interakcji świadomości (a w szczególności zdarzenie opowiadania) wymaga ze strony odbiorcy odpowiedniej postawy mentalnej, zakłada receptywne nas tawienie adresata, korelujące z inicjatywą komunikacyjną podmiotu mówiącego. Słuszne wydaje się nazwanie tego receptywnego nastawienia e to s e m intrygi narracyjnej ${ }^{16}$.

1. Słuchacze z góry znają narracyjne zakończenie baśniowego lub mitotwórczego opowiadania z precedensowym obrazem świata, prowadzonego zgodnie z modalnością poznania. Nawet jeśli z konkretną historią spotykamy się po raz pierwszy, to i tak oczywiste jest, że nie ma podań o nieudanych czynach bohaterskich czy bajek ze złym zakończeniem. Takie narracje charakteryzują się anonimową formą autorstwa i usłyszeć je można niejednokrotnie (w kulturze współczesnej przede wszystkim we wczesnym dzieciństwie). Występujetu rekreatywna intryga odbudowy normalnego biegu życia jako pewnego wspólnego dobra. Zainteresowanie odbiorem narracji jest podtrzymywane nie przez oczekiwanie na końcowy rezultat, lecz przez

13 Ż. Djubua i dr. Obściaja ritorika, Progries, Moskwa 1986, s. 264.

Tamże, s. 275 .

M. Bachtin Słowo w powieści, w: tegoż Problemy literatury i estetyki, s. 107-108.

W zachodniej narratologii ostatnimi czasy również obserwuje się zwrot w stronę kategorii etosu. Zob. L. Altes Ethos and narrative interpretation: the negotiation of values in fiction, University of Nebraska Press, Lincoln 2014. 
niuanse detalizacji i rozwój struktury językowej opowiadania. „Przewidywane słowo odpowiedzi"17 ma przy tym charakter ch ó ral ny, jest identyczne ze słowem wypowiadanym. Receptywne nastawienie adresata takiej wypowiedzi polega na uzyskaniu i zachowaniu przynależności do powszechnie znanego doświadczenia rodzajowego, na chóralnym utożsamieniu się ze wszystkimi s woimi.

Intryga narracyjna Iliady zarówno dla starożytnych Greków, jak i dla nas nie zasadza się na tym, co się stanie z bohaterami, lecz na tym, jaki będzie nasz odbiór tego, co jest powszechnie znane. Mandelsztam wyjaśniał to zdarzenie czytelnicze w znakomitym Znowu bezsenność. Homer. I żagle napięte ${ }^{18}$. Jako etos narracyjny podobnego typu opowieści występuje etos po koju, przezwyciężenia niepokoju, zachowania i podtrzymania precedensowego porządku świata. Jak zauważył Pierre Teilhard de Chardin, „,niepokój jest ściśle związany ze świadomością refleksyjną [...], a zatem towarzyszy człowiekowi od chwili jego pojawienia się na Ziemi”"19, z aktualizacją myślącego „ja”. Moralny stan pokoju zakłada brak troski, beztroskie „ja” zostaje zredukowane, osłabia swoją indywidualność (samost').

Pokój jako pozbycie się strachu przed otaczającą rzeczywistością jest podstawową arcywartością w przestrzeni komunikacyjnej mitu. W kulturze współczesnej narracje pokoju funkcjonują przede wszystkim, choć nie wyłącznie, wśród dziecięcych odbiorców. Narracyjna aktualizacja arcywartości pokoju jest zazwyczaj realizowana poprzez intrygę wzmożenia, a następnie oddalenia czynników grozy, straty, zatroskania, które definiują inwariant cyklicznego (mitotwórczego) sjużetu: strata - poszukiwanie - zdobycie ${ }^{20}$.

Schematy sjużetu nie są zresztą jednoznacznie związane z etosem intrygi. Jako jaskrawy przykład narracji wpisującej się w przednarracyjną (mitopodobną) strategię narracyjną może służyć Odejście (Ischod) Iwana Bunina, w którym śmierć przybiera status precedensowego quasi-świątecznego zdarzenia „odejścia duszy z ciała”21. Zachodzi ono, „nie naruszając jasnego

17 M. Bachtin Słowo w powieści, s. 107.

18 O. Mandelsztam Znowu bezsenność, przeł. S. Pollak, w: tegoż Poezje, wybór M. Leśniewska, Wydawnictwo Literackie, Kraków-Wrocław 1983, s. 115.

P.T. de Chardin Fenomen człowieka, przeł. K. Waloszczyk, PAX, Warszawa 1993, s. 183. Zob. P.A. Grincer Driewnieindijskij epos. Gieniezis i tipołogija, Nauka, Moskwa 1974.

21 I. Bunin Odejście, przeł. S. Pollak, w: tegoż Gramatyka miłości i inne opowiadania, Czytelnik, Warszawa 1972, s. 337. 
i pięknego panowania nocy, czyniąc je tylko jeszcze bardziej pięknym"22. Przy czym etos pokoju jest realizowany zwłaszcza dzięki nieobecności głównego bohatera, dekoncentracji aktantnego „ja”, co tłumaczy bynajmniej niecykliczną budowę sjużetu.

2. Dla parenetycznych narracji o budowie przypowieściowej (z imperatywnym obrazem świata, zakładającym modalność przekonania) jest typowa moralizatorska intryga pou czenia. Można powiedzieć, że jest ona charakterystyczna nie tylko dla bajek, lecz także znacznie bardziej skomplikowanych pod względem literackim tekstów Lwa Tołstoja. Zainteresowanie narracją jest tu zogniskowane wokół ostatecznej pozytywności bądź negatywności łańcucha zdarzeniowego (przede wszystkim typu liminalnego, jak w historii Bazarowa Iwana Turgieniewa). Kompetencja narracyjna adresatów narracji moralizatorskiej polega na zdolności wyciągania wniosków, wartości moralnych, pouczających lekcji z odebranych historii.

Receptywne nastawienie podobnego typu można określić jako etos p o w i n n o ś c i w stosunku do normatywnych zasad porządku świata, kanonicznego wzoru, formalności stosunków międzyludzkich. Tak właśnie etos retoryczny był pojmowany przez Arystotelesa: „dokonaliśmy więc zestawienia toposów, z których należy tworzyć entymemy dotyczące dobra i zła, tego, co szlachetne i brzydkie, sprawiedliwe i niesprawiedliwe, charakterów i afektów oraz postawy etycznej [mówcy]"23. Etos powinności zakłada ze strony adresata oczekiwanie na „przykłady i pouczenia o polityce i dobrych manierach"24.

Organizowanie narracji na normatywnych podstawach jest w pewien sposób alternatywne wobec etosu pokoju, ponieważ zawiera impuls nieskończonej troski o wartość swojej pozycji, całkowite wypełnianie obowiązku, legitymizację wypowiedzi itp. Taka troska uwypukla jednak nie indywidualne ja, lecz imperatywność porządku świata. Obowiązek to ponadindywidualna powinność, to troska niwelująca różnorodność odmiennych „ja”, akcentująca w nich z a ci e n i o ną negatywną stronę. W Martwych duszach, gdzie występuje narracja strategii przypowieściowej z quasi-awanturniczą intrygą, Gogolowski narrator, zwracając się do czytelników, proroczo wyjaśniał etos powinności: „A kto spośród was, pełen chrześcijańskiej pokory, nie

Tamże, s. 343 .

Arystoteles Retoryka. Retoryka dla Aleksandra. Poetyka, przeł. H. Podbielski, Wydawnictwo Naukowe PWN, Warszawa 2004, s. 149.

M.W. Łomonosow Połnoje sobranije soczinienij, w 11 tomach, Izdatielstwo Akademii Nauk SSSR, Moskwa-Leningrad 1952, t. 7, s. 346. 
publicznie, lecz w ciszy, sam, w chwilach samotnych rozmów z samym sobą skieruje do wnętrza własnej duszy to ciężkie pytanie: «A czy i we mnie nie ma czegoś z Cziczikowa?»"25.

3. Okazjonalny obraz świata narracji w modalności poglądów sprzyja awanturniczej intrydze przygody: receptywne nastawienie słuchacza polega na paradoksalnym oczekiwaniu nieoczekiwanego. Przygodowa intryga zagadki (zakładającej odgadnięcie, w innym wypadku słuchanie albo czytanie nie miałoby sensu) jest właśnie in tryg ą w bardziej potocznym i wąskim znaczeniu tego słowa. Przy czym dla receptywnej świadomości, mówiąc słowami Gilles'a Deleuze'a, „nie ma tu żadnych reguł uprzednich, a każda kolejna [receptywna - W.T.] zagrywka określa własne reguły, gra o własne zasady gry"26. Tak więc Ostapa Bendera nie można uznać ani za bohatera pozytywnego, ani negatywnego: czytelnicy powieści Ilji Ilfa i Jewgienija Pietrowa $\mathrm{w}$ istocie mogą dowolnie oceniać pod względem etycznym i politycznym wyczyny oraz sytuację życiową tej postaci.

Intrydze awanturniczej, zazwyczaj rozwijającej się na podstawie kumulatywnego schematu sjużetu, jako receptywne nastawienie adresata odpowiada etos ży c z e ni a, u którego podstaw leży wewnętrzna wolność i samowystarczalność ludzkiego „ja”. Życzenie jest impulsywne, samowolne, życzenie także jest troską, ale troską o in dy wi d u al no ść (samost'), stan moralny wyostrzonej samoświadomości. Ten etos receptywnego zachowania czytelnika Lew Tołstoj wyraził w Annie Kareninie: „Czytając, jak bohaterka romansu dogląda chorego, Anna sama miała ochotę chodzić cichymi krokami po pokoju pacjenta; czytając o członku parlamentu wygłaszającym przemówienie, pragnęła sama wypowiedzieć tę mowę; czytając, jak lady Mary konno cwałowała za gończymi, jak dokuczała bratowej i jak zadziwiała wszystkich odwagą, Anna pragnęła czynić to samo"27. Tołstojowska narracja wpisuje się jednak w etos powinności (co od samego początku sygnalizuje epigraf) i oto jak zmienia się odbiór Anny: „Bohater powieści zaczynał już osiągać szczyt swego typowego angielskiego szczęścia - tytuł baroneta oraz majątek i Anna właśnie miała ochotę wybrać się z nim do jego posiadłości, gdy nagle poczuła, że właściwie powinien on się wstydzić i że tak samo ona się wstydzi.

25 M. Gogol Martwe dusze, przeł. W. Broniewski, Wydawnictwo TPPR „Współpraca”, Warszawa 1987, s. 204.

G. Deleuze Logika sensu, przeł. G. Wilczyński, M. Herer, Wydawnictwo Naukowe PWN, Warszawa 2011, s. 92. 
«Czegóż to on ma się wstydzić? Czemu i ja się wstydzę?» - spytała sama siebie urażona i zdziwiona"28. Oczywiste jest, że podobnych g o g o l o w s k i c h pytań, skierowanych „do wnętrza własnej duszy"29, Tołstoj oczekiwał także od czytelnika.

Charakterystykę życzenia jako nowego, nienormatywnego etosu kultury rozwinął Arthur Schopenhauer. Jeśli, podążając za etosem powinności,,,człowiek [...] mógłby [...] uznać jakąś rzecz za dobrą i na skutek tego jej chcieć", to egocentryczny podmiot czasów nowożytnych „najpierw jej chciał, a potem nazwał dobrą [...], czynność woli jest podstawą jego istoty"30. W szczególności receptywne nastawienie życzeniowe daje swobodę czytelniczego „zadowolenia z tekstu" (Roland Barthes) albo przeciwnie - niezadowolenia.

4. Prawdopodobny obraz świata, który jest opowiadany w modalności rozumienia (wytężonej p e r c e p c ji, a nie już osiągniętego z r o z u mi e n i a), sprzyja rozwojowi e nig mat y c z n ej intrygi obj a wi e n i a. Budowa takiej narracji oparta jest nie na gnoseologicznej zagadce, lecz na ontologicznej t a j e m n i cy, zakładającej nie wyczerpanie intrygi przez rozwikłanie, ale jedynie ciąg wyjaśnień, przybliżeń, dotknięcie niedostępnego dla ludzkiego doświadczenia aspektu życia. Jaskrawym przykładem sjużetu opartego na perypetiach z intrygą objawienia jest Doktor Żywago Borysa Pasternaka ${ }^{31}$.

Awanturnicza intryga odgadywania zagadek rozróżnia dwie świadomości (narratora, znającego rozwiązanie, i adresata, czekającego na nie), ma dywergentny charakter. Odwrotnie rzecz ma się z konwergentną intrygą objawienia, która łączy te świadomości, nie wiodąc ich do tożsamości chóralnej czy roli. Zdarzenie opowiadania w danym przypadku jest realizowane jako komunikacyjny akt solidarności (a nie podporządkowania czy arbitralności). To „poparcie, wzbogacające słowo" ${ }^{32}$ ze strony mowy wewnętrznej adresata. Dla narratora i adresata opowiadania enigmatycznego niezbędna jest wspólna płaszczyzna porozumienia. Przed obliczem ogólnej tajemnicy bytu

\footnotetext{
28 Tamże, s. 116.

29 M. Gogol Martwe dusze, s. 204. A. Schopenhauer Świat jako wola i przedstawienie, t. 1, przeł. i oprac. J. Garewicz, Wydawnictwo Naukowe PWN, Warszawa 1994, s. 447. Poetika "Doktora Żywago" w narratołogiczeskom procztienij, red. W.I. Tiupa, Izdatielstwo Intriga, Moskwa 2014. 
aktualizowane jest „wzajemne uznanie między podmiotami”"33 (jak i uznanie autonomicznej subiektywności bohaterów historii). Etos takiej intrygi jest etosem indywidualnej odpowiedzialności, którą należy odróżnić od ponadindywidualnej powinności, tzn. etosu indywidualnego samookreślenia (a nie gogolowskiego samooceny moralnej).

Moralny stan odpowiedzialności to dialogiczna troska o Innego: czy moje życie odpowiada na potrzeby innego życia? Czy jestem dla niego interesujący i potrzebny? Czy zasługuję na czyjąś uwagę i zaufanie?, itp. Otwarte zakończenia Antona Czechowa, wzbudzające wątpliwości co do zdarzeniowości jego historii ${ }^{34}$, są enigmatyczne w tym sensie, że nie rozwiązują intrygi, pobrzmiewają "pękającą struną"35 z końcówki Wiśniowego sadu. Tym samym kierują pytania egzystencjalne podobnego rodzaju do świadomości percepcyjnej, inercjalnie przewidującej takie czy inne rozwiązanie intrygi. Narrator w milczeniu obarcza odpowiedzialnością za stojący przed bohaterem wybór życiowy ${ }^{36}$ czytelnika, jego gotowość do indywidualnego samookreślenia.

Oczywiście intryga enigmatyczna nie sprowadza się tylko do kompozycyjnego zasobu otwartego zakończenia. Chodzi tu przede wszystkim o implicytny system wartości, karmiący zainteresowanie czytelnika. Tak, zainteresowanie narracją Doktora Żjwago nie polega na tym, że tytułowy bohater miał żonę i kochankę (to systemy wartości obce tej powieści pouczającej i intrydze awanturniczej); wynika raczej z pytania: dlaczego trzem kobietom był on życiowo potrzebny (jak Chrystus Magdalenie)?

Wyjaśniając strategię narracyjną tego czy innego sjużeto-narracyjnego dyskursu, trzeba zawsze mieć na uwadze receptywny element strategii, określony tu terminem „etos”, a mianowicie stan moralny odpowiedniego uczestnictwa w zdarzeniu opowiadania.

Przeł. Agnieszka Ścibior

33 P. Ricoeur Wyzwanie semiologiczne: problem podmiotu, przeł. E. Bieńkowska, w: tegoż Egzystencja i hermeneutyka. Rozprawy o metodzie, wybór S. Cichowicz, De Agostini, Warszawa 2003, s. 286.

34 W. Szmid Proza kak poezija: Puszkin, Dostojewskij, Czechow, awangard, Inapriess, Sankt-Pietierburg 1998.

35 A. Czechow Wiśniowy sad, przeł. C. Jastrzębiec-Kozłowski, w: tegoż Wujaszek Wania. Trzy siostry. Wiśniowy sad, Świat Literacki, Warszawa 1994, s. 238.

36 Zob. W. Tiupa Funkcyja czitatiela w czechowskom narratiwie, "Russkaja Litieratura” 2010 nr 3 , s. $45-50$. 


\section{Abstract}

\section{Valerii Tiupa}

RUSSIAN STATE UNIVERSITY FOR THE HUMANITIES

The Ethos of the Narrative Plot

Tiupa explores one of the strategic aspects of narrative discourse and the problem of innovative narratological research. Building on Paul Ricoeur's notion of the discourse of narrative plot, Tiupa introduces the rhetorical category of the "ethos" that supports the typological characterisation of different phenomena of narrative literary production.

\section{Keywords}

ethos, narrative, discourse, plot, Paul Ricoeur 